\title{
Aplikasi Pendaftaran Pasien Berbasis Android pada Apotek Cordelia Tanjungpinang
}

\author{
Rio Ari Prasetio ${ }^{1}$, Nanny Raras Setyoningrum ${ }^{2}$, Ira Purnamasari ${ }^{3}$ \\ ${ }^{1,2,3}$ Program Studi Teknik Informatika STT Indonesia Tanjungpinang \\ ${ }^{2}$ Program Studi Sistem Informasi Konsentrasi Komputer Akuntansi STT Indonesia Tanjungpinang \\ Jln. Pompa Air No. 28 Tanjungpinang Kepulauan Riau Indonesia \\ ${ }^{1}$ rioaprasetio17@gmail.com \\ ${ }^{2}$ nannysetyoningrum141@gmail.com \\ 3irawupurnamasari@gmail.com
}

\begin{abstract}
Intisari- Telepon seluler adalah sebuah fenomena yang paling menarik menjelah akhir abad lalu. Fenomena yang dimulai pada tahun 1990-an dan berkembang hingga sekarang Telepon seluler kini memiliki System Operasi yang mampu mengatur dan mengontrol semua aplikasi-aplikasi, ada bermacam-macam system operasi misalnya Symbian, Windows Mobile, Palm, Blackberry dan Android yang baru saat ini. Dengan demikian penulis tertarik untuk membuat sebuah aplikasi android yang memudahkan orang untuk berobat di klinik kesehatan. Sistem yang dibuat ini adalah sistem yang memudahkan orang dalam melihat nomor antrian sehingga orang yang akan berobat tidak perlu menunggu terlalu lama di klinik. Dalam perancangan class ini metodologi penelitian yang digunakan adalah pengumpulan data. Metode pengumpulan data terdiri dari studi kepustakaan dan eksperimen. Aplikasi Pendaftaran Pasien Berbasis Android Pada Apotek Cordelia Dan Praktek Dokter Umum Jl. RE. Martadinata Tanjungpinang ini diimplementasikan berdasarkan analisis kebutuhan dengan menggunakan aplikasi android, bahasa pemograman PHP dan Java, PHP MySql sebagai tempat penampung database.
\end{abstract}

Kata kunci- Android, apotek, antrian, Java, PHP MySql.

Abstract-Cell phones are a phenomenon of the most interest since the end of the last century. A phenomenon that began in the 1990s and develops until now. Cellular phones now have an Operating System that is able to manage and control all applications, there are various operating systems such as Symbian, Windows Mobile, Palm, Blackberry and Android which are new today. Thus the authors are interested in creating an android application that makes it easy for people to seek treatment at a health clinic. The system created is a system that makes it easier for people to see the queue number so that people who are going for treatment do not have to wait too long at the clinic. In designing this class the research methodology used is data collection. The data collection method consisted of literature study and experiment. Android-Based Patient Registration Application at Cordelia Pharmacy and General Practitioner Practices Jl. RE. Martadinata Tanjungpinang is implemented based on a needs analysis using Android applications, PHP and Java programming languages, PHP MySql as a database.

Keywords-Android, pharmacy, queue, Java, PHP MySql.

\section{Pendahuluan}

Telepon seluler adalah sebuah fenomena yang paling menarik menjelah akhir abad lalu. Fenomena yang dimulai pada tahun 1990-an dan berkembang hingga sekarang Telepon seluler kini memiliki System Operasi yang mampu mengatur dan mengontrol semua aplikasi-aplikasi, ada bermacammacam system operasi misalnya Symbian, Windows Mobile, Palm, Blackberry dan Android yang baru saat ini. Android adalah System Operasi yang diciptakan oleh perusahaan besar yaitu Google. Android juga berbasiskan Linux, OpenSource dan juga menyediakan platform terbuka bagi para pengembang buat menciptakan aplikasi mereka sendiri untuk digunakan oleh bermacam peranti bergerak seperti mobile.

Pengguna telepon seluler kini tidak terbatas hanya pada mereka yang berbisnis saja, faktanya sejak anak sudah mulai memasuki usia sekolah di Tingkat Dasar pun mereka sudah diperkenalkan dengan telepon seluler. Telepon seluler bisa saja berdampak positif dan negatif jika diperkenalkan sejak dini kepada anak. Pada zaman perkembangan seperti ini juga sangat berpengaruh kepada teknologi di bidang kesehatan. Pelayanan klinik untuk berobat masih saja menemukan beberapa masalah, yang diantaranya tentang pelayanan petugas dalam memberikan nomor antrean serta pelayanan lainnya. Bahkan banyak masyarakat yang sering mengeluh karna lamanya mengantri. Hal tersebut membuat tingkat kepuasan masyarakat teradap layanan medis menurun. Keluhan masyarakat terhadap tingkat pelayanan klinik juga belum dapat di sampaikan dengan jelas, dikarenakan banyak klinik yang tidak menyediakan sarana untuk pengaduan kepuasan pasien. Selain itu juga, tingkat layanan klinik atau rumah sakit dapat di lihat dari jadwal praktek dokter yang kadang tidak teratur. Banyak dokter yang tidak hanya bertugas di satu klinik atau rumah sakit, hal ini membuat jadwal dokter yang sewaktu - waktu dapat berubah. Namun, terkadang informasi ini masih sering tidak di beritahukan ke pasien yang datang.

Berdasarkan latar belakang dan uraian diatas maka penulis tertarik untuk membuat skripsi dibidang kesehatan menggunakan sistem android dengan judul "Aplikasi Pendaftaran Pasien Berbasis Android Pada Apotek Cordelia Tanjungpinang"

\section{Metodologi Penelitian}




\section{A. Pengertian Dokter}

Secara operasional, definisi "Dokter" adalah seorang tenaga kesehatan (dokter) yang menjadi tempat kontak pertama pasien dengan dokternya untuk menyelesaikan semua masalah kesehatan yang dihadapi tanpa memandang jenis penyakit, organologi, golongan usia, dan jenis kelamin, sedini dan sedapat mungkin, secara menyeluruh, paripurna, bersinambung, dan dalam koordinasi serta kolaborasi dengan profesional kesehatan lainnya, dengan menggunakan prinsip pelayanan yang efektif dan efisien serta menjunjung tinggi tanggung jawab profesional, hukum, etika dan moral. Layanan yang diselenggarakannya adalah sebatas kompetensi dasar kedokteran yang diperolehnya selama pendidikan kedokteran.

\section{B. Pengertian Pasien}

Pengertian Pasien menurut Pasal 1 Undang-undang No. 29 Tahun 2004 Tentang Praktik Kedokteran menjelaskan definisi pasien adalah setiap orang yang melakukan konsultasi masalah kesehatannya untuk memperoleh pelayanan kesehatan yang diperlukan baik secara langsung maupun tidak langsung kepada dokter atau dokter gigi.

\section{Hak-Hak Pasien}

Hak-hak yang dimiliki pasien sebagaimana diatur dalam Pasal 52 Undang-undang No.29 Tahun 2004 tentang Praktik Kedokteran, adalah :

a. Mendapatkan penjelasan secara lengkap tentang tindakan medis;

b. Meminta pendapat dokter atau dokter gigi lain;

c. Mendapat pelayanan sesuai dengan kebutuhan medis;

d. Menolak tindakan medis; dan

e. Mendapatkan isi rekam medis.

\section{Kewajiban-Kewajiban Pasien}

Kewajiban pasien yang diatur dalam Pasal 53 Undangundang No. 29 Tahun 2004 tentang Praktik Kedokteran ini adalah :

a. Memberikan informasi yang lengkap dan jujur tentang masalah kesehatanya.

b. Mematuhi nasehat dan petunjuk dokter atau doter gigi.

c. Mematuhi ketentuan yang berlaku disarana pelayanan kesehatan.

d. Memberikan imbalan jasa atas pelayanan yang diterima.

\section{Pengertian Rekam Medis}

Menurut PERMENKES No: 269/MENKES/PER/III/2008 yang dimaksud rekam medis adalah berkas yang berisi catatan dan dokumen antara lain identitas pasien, hasil pemeriksaan, pengobatan yang telah diberikan, serta tindakan dan pelayanan lain yang telah diberikan kepada pasien.

Catatan merupakan tulisan-tulisan yang dibuat oleh dokter atau dokter gigi mengenai tindakan-tindakan yang dilakukan kepada pasien dalam rangka palayanan kesehatan. Bentuk Rekam Medis dalam berupa manual yaitu tertulis lengkap dan jelas dan dalam bentuk elektronik sesuai ketentuan. Rekam medis terdiri dari catatan-catatan data pasien yang dilakukan dalam pelayanan kesehatan.

Catatan-catatan tersebut sangat penting untuk pelayanan bagi pasien karena dengan data yang lengkap dapat memberikan informasi dalam menentukan keputusan baik pengobatan, penanganan, tindakan medis dan lainnya. Dokter atau dokter gigi diwajibkan membuat rekam medis sesuai aturan yang berlaku. Menurut PERMENKES No: 269/MENKES/PER/III/2008 data-data yang harus dimasukkan dalam Medical Record dibedakan untuk pasien yang diperiksa di unit rawat jalan dan rawat inap dan gawat darurat.

\section{Pengertian Aplikasi}

Secara umum, aplikasi merupakan sebuah alat terapan yang difungsikan secara khusus dan terpadu sesuai dengan kemampuan yang dimilikinya. Secara etimologi, aplikasi berasal dari bahasa inggris yaitu Application yang berarti penerapan, lamaran dan penggunaan. Secara istilah aplikasi merupakan sebuah program siap pakai yang dipakai untuk melaksanakan suatu fungsi bagi pengguna atau aplikasi yang lain dpat digunakan oleh sasaran yang dituju.

Dapat dikatakan juga, bahwa aplikasi merupakan suatu perangkat lunak yang siap pakai dengan menjalankan instruksi-instruksi dari pengguna (user), aplikasi banyak diciptakan untuk membantu berbagai keperluan, seperti contoh : membuat laporan, percetakan dan lain-lain.

\section{E. Pengertian Aplikasi Mobile}

Mobile dapat diartikan sebagai perpindahan yang mudah dari satu tempat ke tempat yang lain, misalnya telepon mobile berarti bahwa terminal telepon yang dapat berpindah dengan mudah dari satu tempat ke tempat lain tanpa terjadi pemutusan atau terputusnya komunikasi. Sistem aplikasi mobile merupakan aplikasi yang dapat digunakan walaupun pengguna berpindah dengan mudah dari satu tempat ketempat lain lain tanpa terjadi pemutusan atau terputusnya komunikasi.

\section{F. Dasar-dasar Aplikasi}

Aplikasi Android ditulis dalam bahasa pemrograman Java. Android SDK Tools mengompilasi kode Anda - bersama data dan file sumber daya-menjadi sebuah APK: sebuah paket Android, yang berupa file arsip dengan akhiran .apk. Satu file APK berisi semua materi aplikasi Android dan merupakan file yang digunakan perangkat Android untuk memasang aplikasi.

\section{HASIL DAN PEMBAHASAN}

\section{A. Use Case Diagram Perancangan Sistem}

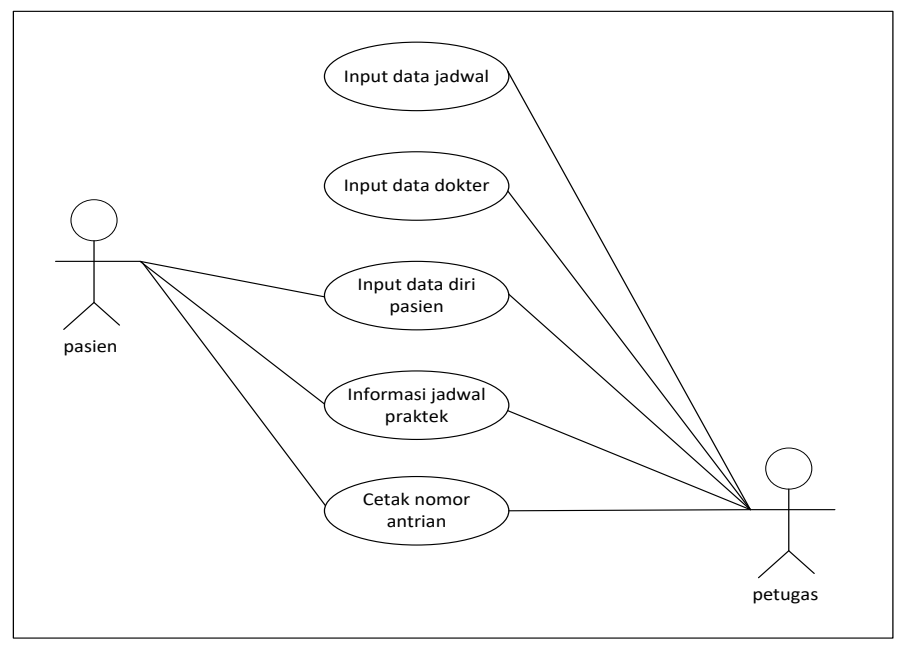

Gambar 1. Use Case Diagram Perancangan Sistem 
Pada Usecase Diagram ini menggambarkan tentang apa saja yang dilakukan user dalam sistem yang dirancang, berikut ini adalah langkah-langkah dari Use Case Diagram Perancangan Sistem :

TABEL I

LANGKAH-LANGKAH USE CASE DIAGRAM

\begin{tabular}{lll}
\hline \multicolumn{1}{c}{ Aktor } & \multicolumn{1}{c}{ Use Case } & \multicolumn{1}{c}{ Deskripsi } \\
\hline Petugas & Input Data Jadwal & $\begin{array}{l}\text { Petugas memasukan data jadwal } \\
\text { praktek dokter }\end{array}$ \\
\hline Petugas & Input Data Dokter & $\begin{array}{l}\text { Petugas memasukan data dokter } \\
\text { yang akan praktek }\end{array}$ \\
\hline $\begin{array}{l}\text { Pasien } \\
\text { Petugas }\end{array}$ & $\begin{array}{l}\text { Input Data Diri } \\
\text { Pasien }\end{array}$ & $\begin{array}{l}\text { Pasien memasukan data diri untuk } \\
\text { mendaftar berobat kemudian } \\
\text { Petugas mengecek kembali data } \\
\text { pasien yang telah dimasukan }\end{array}$ \\
\hline $\begin{array}{l}\text { Pasien } \\
\text { Petugas }\end{array}$ & Informasi Jadwal & $\begin{array}{l}\text { Petugas terlebih dahulu memasukan } \\
\text { informasi mengenai jadwal praktek } \\
\text { klinik, lalu pasien dapat melihat } \\
\text { informasi jadwal praktek yang telah } \\
\text { di masukan oleh petugas }\end{array}$ \\
\hline $\begin{array}{l}\text { Pastek dan } \\
\text { petugas }\end{array}$ & $\begin{array}{l}\text { Cetak nomor } \\
\text { antrian }\end{array}$ & $\begin{array}{l}\text { Pasien yang telah mendaftar, dapat } \\
\text { melihat nomor urut antrian } \\
\text { menunggu, dan petugas dapat } \\
\text { mencetak nomor antrian sebagai } \\
\text { laporan. }\end{array}$
\end{tabular}

B. Activity Diagram Daftar ke Aplikasi Android

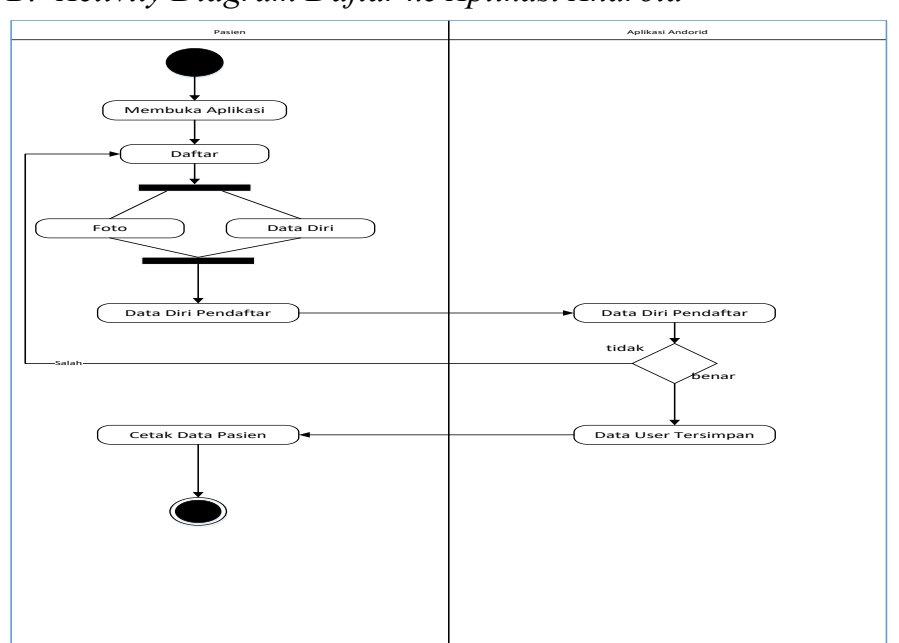

Gambar 2. Activity Diagram Daftar ke Aplikasi android

Pada Activity Diagram ini menggambarkan tentang bagaiana alur berjalannya sistem yang dirancang, berikut ini adalah langkah-langkah dari Activity Diagram Daftar ke Aplikasi Android :

1. Pasien membuka aplikasi

2. Kemudian pilih daftar

3. Kemudian input data diri dan input foto.

4. Kemudian aplikasi android akan memverifikasi data diri pasien, jika tidak lengkap maka pasien harus kembali mendaftar.

5. Jika lengkap maka data akan tersimpan di aplikasi android.

6. Pasien dapat mencetak data diri pasien dan kemudian logout aplikasi.Huruf-huruf Dokumen

\section{Activity Diagram login dan daftar berobat}

Pada Activity Diagram ini menggambarkan tentang bagaiana alur berjalannya sistem yang dirancang, berikut ini adalah langkah-langkah dari Activity Diagram Login dan Pendaftaran Pasien :

1. Pasien membuka aplikasi di perangkat android

2. Kemudian pasien login

3. Aplikasi android memverifikasi username dan password pasien

4. Jika salah maka, pasien harus mengisi username dan password kembali, namun jika benar maka aplikasi android akan menampilkan dasboard

5. Pasien dapat memilih jadwal pemeriksaan dan data antrian.

6. Pasien pilih menu jadwal periksa, maka akan aplikasi android akan menampilkan beberapa jadwal periksa.

7. Setelah memilih jadwal periksa maka aplikasi akan memverifikasi jadwal yang terpilih.

8. Jika jadwal yang dipilih tidak ada, maka pasien harus kembali memilih jadwal periksa.

9. Jika jadwal yang dipilih ada, maka aplikasi android akan menampilkan form keluhan penyakit dan data diri.

10. Setelah mengisi keluhan penyakit dan data diri, maka aplikasi android akan menampilkan nomor antrian.

11. Pasien dapat mencetak nomor antrian.

12. Kemudian logout dari aplikasi.

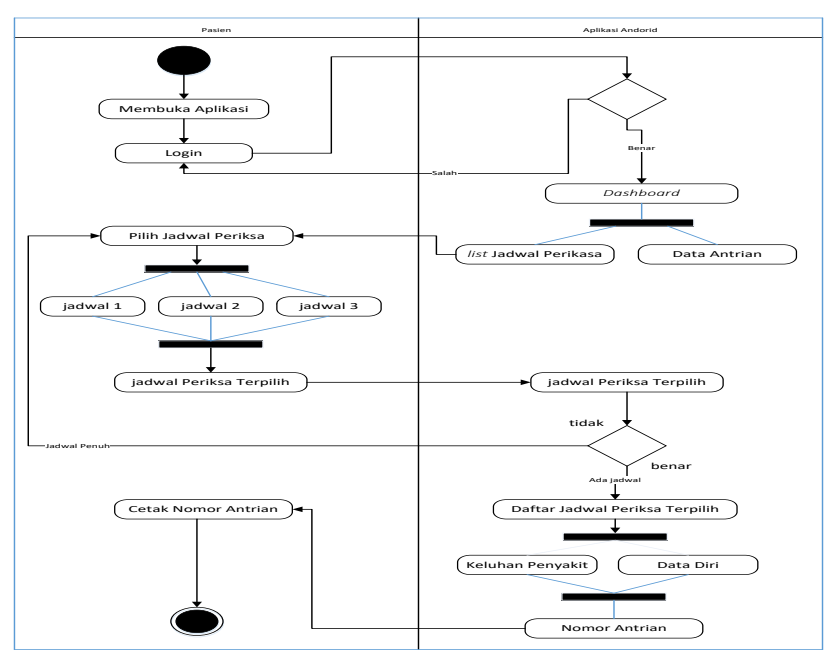

Gambar 3. Activity Diagram Login dan daftar berobat

\section{Activity Diagram Posisi Antrian}

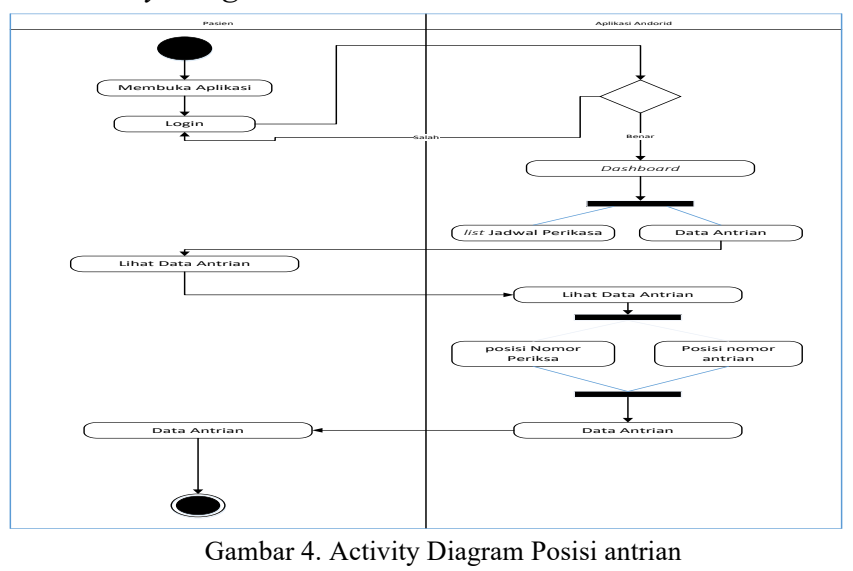

Pada Activity Diagram ini menggambarkan tentang bagaiana alur berjalannya sistem yang dirancang, berikut ini adalah langkah-langkah dari Activity Diagram Posisi antrian : 
1. Pasien membuka aplikasi di perangkat android

2. Kemudian pasien login

3. Aplikasi android memverifikasi username dan password pasien

4. Jika salah maka, pasien harus mengisi username dan password kembali, namun jika benar maka aplikasi android akan menampilkan dasboard

5. Pasien dapat memilih menu data antrian.

6. Pasien pilih menu data antrian, maka akan aplikasi android akan menampilkan menu posisi nomor antrian dan posisi nomor periksa.

7. Setelah itu aplikasi android menampilkan data antrian yang dipilih pasien.

8. Kemudian pasien dapat logout aplikasi.

\section{E. Sequence Diagram Daftar Aplikasi}

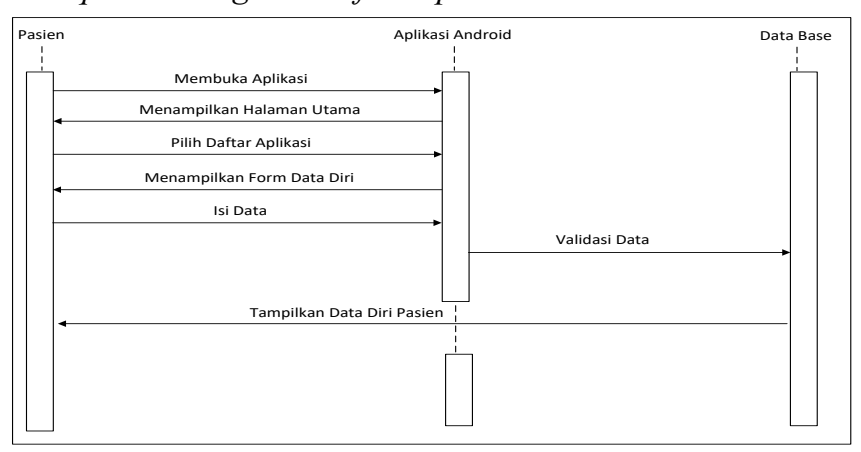

Gambar 5. Squence Diagram Daftar Aplikasi Android

Penjelasan Squence Diagram Daftar ke Aplikasi Android:

Pada Squence Diagram ini menjelaskan tentang tahapan sistem yang berjalan menurut waktu, berikut ini adalah langkah-langkahnya :

1. Pasien membuka aplikasi

2. Kemudian pilih daftar

3. Aplikasi menampilkan form pengisian data diri

4. Kemudian input data diri

5. Data diri yang diisi akan tersimpan di dalam database dan di validasi.

6. Kemudian data pasien akan ditampilkan

\section{F. Sequence Diagram login dan Berobat}

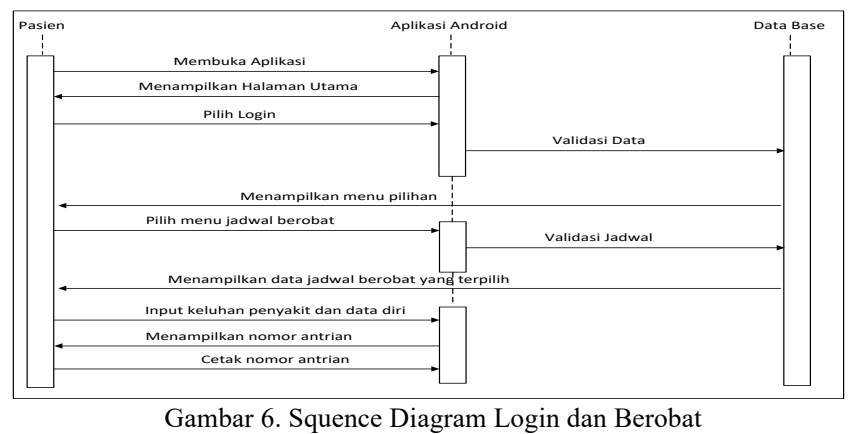

Penjelasan Squence Diagram Login dan Berobat :

Pada Squence Diagram ini menjelaskan tentang tahapan sistem yang berjalan menurut waktu, berikut ini adalah langkah-langkahnya :

1. Pasien membuka aplikasi di perangkat android

2. Kemudian pasien login

3. Validasi data login ke database
4. Pasien pilih menu jadwal periksa, maka akan aplikasi android akan menampilkan beberapa jadwal periksa.

5. Setelah memilih jadwal periksa maka aplikasi akan memverifikasi jadwal yang terpilih.

6. Lalu aplikasi android akan menampilkan form keluhan penyakit dan data diri.

7. Setelah mengisi keluhan penyakit dan data diri, maka aplikasi android akan menampilkan nomor antrian.

8. Pasien dapat mencetak nomor antrian.

\section{G. Sequence Diagram Posisi Antrian}

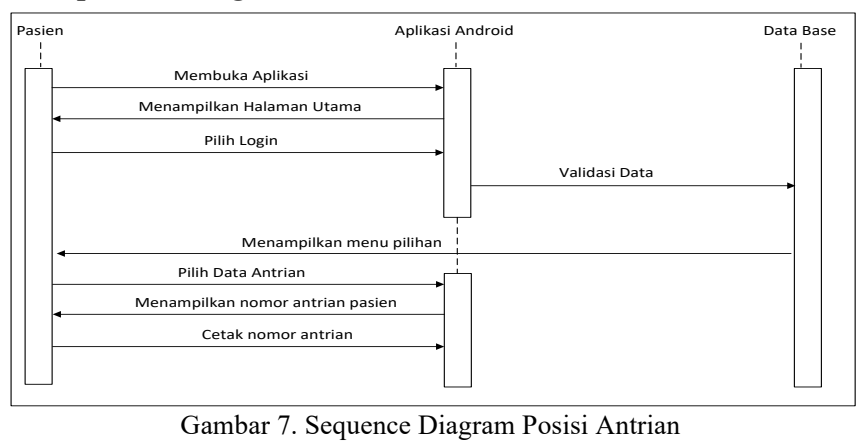

Pada Sequence Diagram ini menjelaskan tentang tahapan sistem yang berjalan menurut waktu, berikut ini adalah langkah-langkahnya :

1. Pasien membuka aplikasi di perangkat android

2. Kemudian pasien login

3. Validasi data login

4. Pasien dapat memilih menu data antrian.

5. Pasien pilih menu data antrian, maka akan aplikasi android akan menampilkan menu posisi nomor antrian dan posisi nomor periksa.

6. Setelah itu aplikasi android menampilkan data antrian yang dipilih pasien.

7. Pasien dapat mencetak nomor antrian.

\section{H. Class Diagram Keseluruhan Sistem}

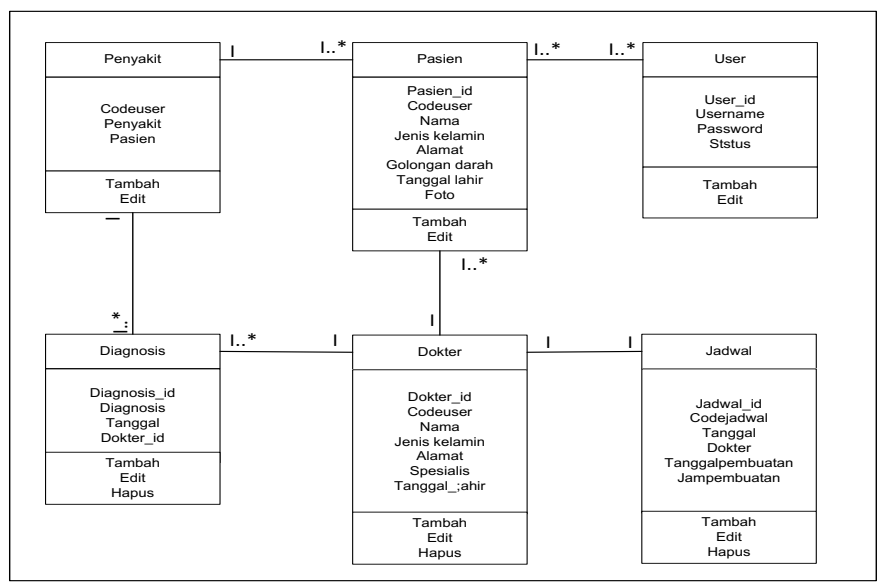

Gambar 8. Class Diagram Keseluruhan Sistem

\section{Pengujian Black Box}

Pengujian sistem yang dilakukan untuk memeriksa kekompakan antar komponen sistem, dengan tujuan utamanya adalah untuk memastikan elemen-elemen sistem yang berfungsi sesuai dengan yang diharapkan. Pengujian sistem termasuk juga pengujian program secara menyeluruh. 
Kumpulan program dapat menerima dengan baik, memproses dan memberikan hasil keluaran program yang baik juga.

TABEL II

PELAKSANAAN PENGUJian BLACK BOX

\begin{tabular}{|c|c|c|c|}
\hline $\begin{array}{c}\text { Modul yag } \\
\text { diuji }\end{array}$ & Proses Pengujian & $\begin{array}{l}\text { Hasil yg } \\
\text { Dicapai }\end{array}$ & $\begin{array}{c}\text { Hasil yg } \\
\text { Diharapkan }\end{array}$ \\
\hline $\begin{array}{l}\text { Register } \\
\text { Account Pasien }\end{array}$ & $\begin{array}{l}\text { Pasien megisi data } \\
\text { diri pada form } \\
\text { register account } \\
\text { pasien dengan } \\
\text { memasukan nama, } \\
\text { jenis kelamin, } \\
\text { alamat, kontak, } \\
\text { email, password }\end{array}$ & $\begin{array}{l}\text { Menampilkan } \\
\text { form selanjutnya } \\
\text { untuk dapat } \\
\text { login ke aplikasi }\end{array}$ & $\begin{array}{l}\text { Data pasien } \\
\text { dapat tersimpan } \\
\text { dalam database }\end{array}$ \\
\hline login & $\begin{array}{l}\text { Pasien yang telah } \\
\text { berhasil mendaftar } \\
\text { account, maka } \\
\text { harus login dengan } \\
\text { email dan } \\
\text { password yang } \\
\text { telah dimiliki }\end{array}$ & $\begin{array}{l}\text { Menampilkan } \\
\text { menu pilihan }\end{array}$ & $\begin{array}{l}\text { Data login } \\
\text { tersimpan } \\
\text { dalam database }\end{array}$ \\
\hline $\begin{array}{l}\text { Daftar jadwal } \\
\text { pemeriksaan }\end{array}$ & $\begin{array}{l}\text { Pilih dokter dan } \\
\text { masukan keluhan } \\
\text { pasien }\end{array}$ & $\begin{array}{l}\text { Menampilkan } \\
\text { data pasien yang } \\
\text { telah mendaftar } \\
\text { jadwal } \\
\text { pemeriksaan }\end{array}$ & $\begin{array}{l}\text { Data } \\
\text { pendaftaran } \\
\text { pasien } \\
\text { tersimpan }\end{array}$ \\
\hline $\begin{array}{l}\text { Antrian rekam } \\
\text { medis }\end{array}$ & $\begin{array}{l}\text { Data yang muncul } \\
\text { akan berupa } \\
\text { nomor antrian } \\
\text { pasien }\end{array}$ & $\begin{array}{l}\text { Nomor antrian } \\
\text { pasien akan } \\
\text { muncul secara } \\
\text { otomatid }\end{array}$ & Data muncul \\
\hline $\begin{array}{l}\text { Edit profil } \\
\text { pasien }\end{array}$ & $\begin{array}{l}\text { Pilih data yang } \\
\text { akan diedit }\end{array}$ & $\begin{array}{l}\text { Data yang diedit } \\
\text { akan berubah }\end{array}$ & $\begin{array}{l}\text { Data yang telah } \\
\text { di edit akan } \\
\text { tersimpan }\end{array}$ \\
\hline Jadwal dokter & $\begin{array}{l}\text { Menginput jadwal } \\
\text { dokter yang } \\
\text { praktek }\end{array}$ & $\begin{array}{l}\text { Jadwal praktek } \\
\text { dokter akan } \\
\text { tampil pada } \\
\text { aplikasi } \\
\end{array}$ & $\begin{array}{l}\text { Jadwal praktek } \\
\text { yang telah } \\
\text { diinputkan akan } \\
\text { tersimpan }\end{array}$ \\
\hline Data dokter & $\begin{array}{l}\text { Masukan data diri } \\
\text { dokter }\end{array}$ & $\begin{array}{l}\text { Data dokter yang } \\
\text { dimasukan akan } \\
\text { muncul }\end{array}$ & $\begin{array}{l}\text { Data dokter } \\
\text { tersimpan }\end{array}$ \\
\hline $\begin{array}{l}\text { Data diagnosa } \\
\text { dokter }\end{array}$ & $\begin{array}{l}\text { Masukan data } \\
\text { diagnosa pasien } \\
\text { sesuai keluhan } \\
\text { pasien }\end{array}$ & $\begin{array}{l}\text { Data diegnosa } \\
\text { akan tampil } \\
\text { setelah } \\
\text { dimasukan } \\
\end{array}$ & $\begin{array}{l}\text { Data diagnosa } \\
\text { akan tampil dan } \\
\text { tersimpan } \\
\text { secara otomatis }\end{array}$ \\
\hline $\begin{array}{l}\text { Cetak nomor } \\
\text { antrian }\end{array}$ & $\begin{array}{l}\text { Pilih cetak nomor } \\
\text { antrian }\end{array}$ & $\begin{array}{l}\text { Data nomor } \\
\text { antrian yang } \\
\text { dipilih akan } \\
\text { muncul } \\
\end{array}$ & $\begin{array}{l}\text { Nomor antrian } \\
\text { akan muncul } \\
\text { sesuai antrian } \\
\text { pasien }\end{array}$ \\
\hline
\end{tabular}

\section{J. Hasil Implementasi Program}

Berikut gambar-gambar hasil implementasi pada Aplikasi Pendaftaran Pasien Berbasis Android Pada Apotek Cordelia Dan Praktek Dokter Umum Jl. RE. Martadinata Tanjungpinang adalah sebagai berikut :

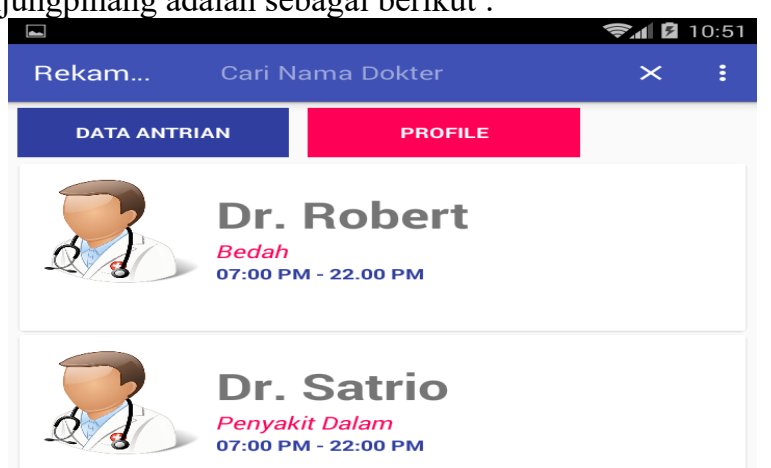

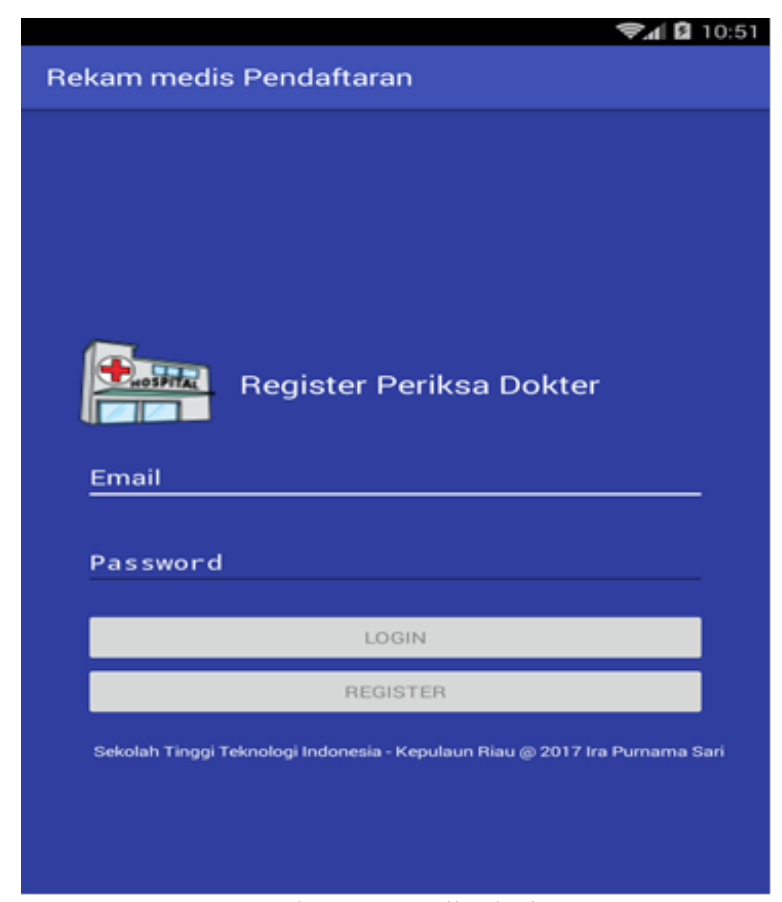

Gambar 10. Tampilan login

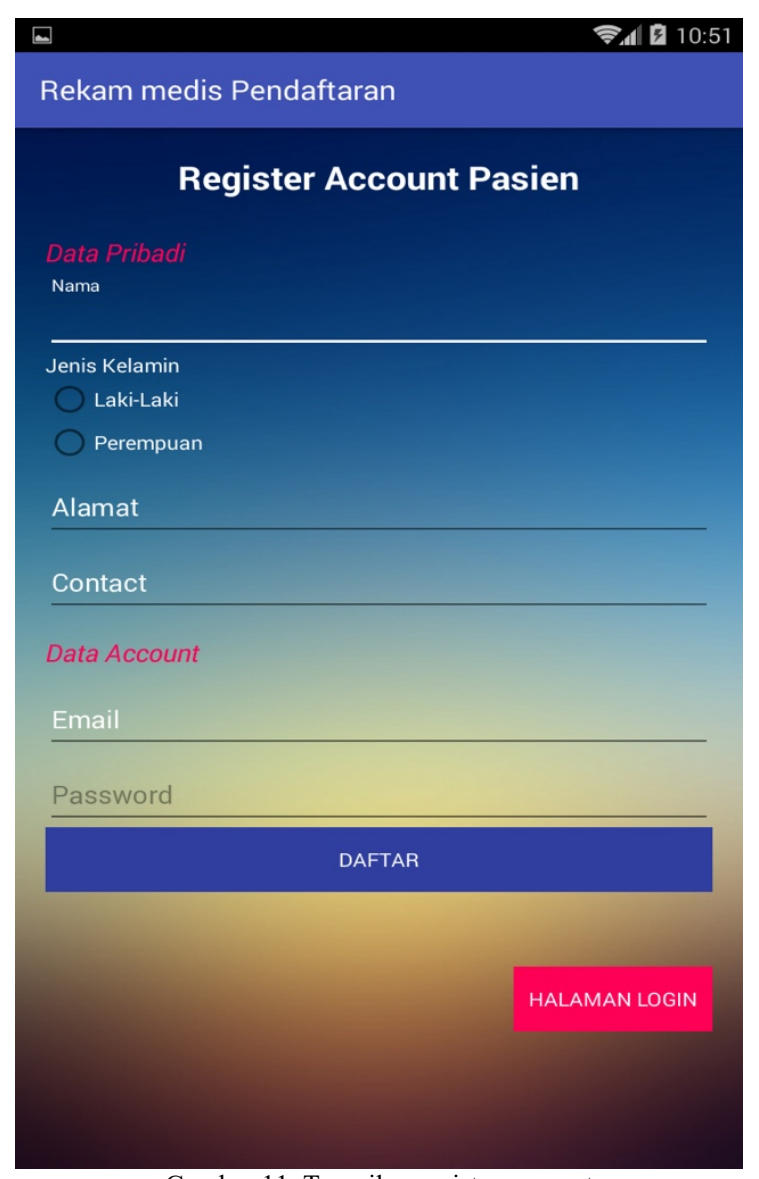

Gambar 11. Tampilan register account 


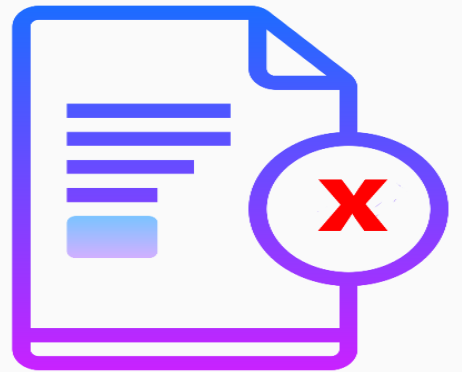

Anda Belum ada Jadwal Pendaftaran

DAFTAR SEKARANG

Gambar 12. Tampilan jadwal yang belum terdaftar

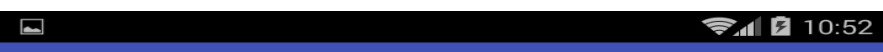

Rekam medis Pendaftaran

Sekarang Antrian Ke - 08

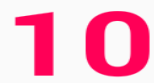

Keluhanmu

Gambar 13. Tampilan nomor antrian

\section{KESIMPULAN}

Berdasarkan hasil proses perancangan dan pembuatan Aplikasi Pendaftaran Pasien Berbasis Android Pada Apotek Cordelia Tanjungpinang, penulis menyimpulkan bahwa :

1. Aplikasi ini dibuat menggunakan android untuk dapat memudahkan pasien dalam mendaftarkan diri untuk berobat di klinik.
2. Setelah dilakukan uji coba, nomor antrian pasien dapat secara otomatis mucul ketika pasien telah mendaftarkan diri.

3. Aplikasi ini juga memudahkan dokter dalam melihat keluhan pasien dan data diri pasien.

4. Jadwal klinik dapat dengan mudah dilihat hanya dengan sebuah SmartPhone.

5. Aplikasi yang dibuat ini dapat memudahkan membantu petugas dalam membuat sebuah laporan pasien dan dokter.

\section{UCAPAN TERIMA KASIH}

Penulis Mengucapkan rasa terima kasih kepada pihak-pihak yang telah membantu dalam menyelesaikan penelitian ini terutama kepada pihak dokter-dokter serta pihak kampus Sekolah Tinggi Teknologi Indonesia Tanjungpinang.

\section{REFERENSI}

[1] S. M. Metev and V. P. Veiko, Laser Assisted Microtechnology, 2nd ed., $\mathrm{R}$ Anonim.Panduan KP dan TA STT INDONESIA TANJUNGPINANG, 2014, Tanjungpinang.

[2] Sommerville, Ian, Software Engineering (Rekayasa Perangkat Lunak), 2011, Erlangga, Jakarta

[3] Afief Ramadhan, Hendra Saputra, PHP5 dan MySq1, Elex Media Komputindo, 2005.

[4] Herry Purnomo, Theo Zacharias, , Pengenalan Informatika Perpektif Teknik dan Lingkungan, [ Penerbit ANDI, 2005 ].

[5] Hanif Al Fatta, Analisis dan Perancangan Sistem Informasi Untuk Keunggulan Bersaing Perusahaan \& Organisasi Modern ( Yogyakarta : Andi )

[6] Wiranto Herry Utomo, Pemodelan Basis Data Berorientasi Objek, [ Andi, 2010, Yogyakarta ].

[7] Fikri Awan, Konsep Permodelan Dengan UML, [ diakses 1 Agustus 2017, Pukul 15.30 wib ].

[8] Masrul Nur, Aplikasi Penerapan Teknologi Augmented Reality Untuk Penanganan Penderita Stroke Berbasis Android [ Naskah Publikasi ].

[9] Donald Bell, The Sequence Diagram, diakses dari http://www.ibm.com/developerworks/rational/library/3101.html $\quad[12$ Agustus 2017, 15.34 WIB].

[10] M. Rhandy Kahfi. Sistem Informasi Pada Point Of Sales Berbasis Android Barcode Scanner [ Skripsi, 2016].

[11] http://www.ibm.com/developerworks/rational/library/3101.htmldiakses, 1 Agustus 2016,pukul 09.27 wib ].

[12] Jubilee Enterprise, Mengenal Dasar - Dasar Pemrograman Android [ PT Elex Media Komputindo, 2015 ].

[13] Guruh Rio Samudra, Aplikasi Pencatatan Penjualan Model Two - Tier Berbasis Android[ Skripsi, 2013 ].

[14] http://www.kompasiana.com/ardiantri/sekilas-tentang-appserv-dancara-install-appserv-pada komputer_551915be813311fb739de0d8 [ diakses Sabtu, 14 Mei 2017, pukul 13.00 wib ] 